\title{
Integration sites of the HTLV-1 provirus in host human genome in the IDH patients with monoclonal integration
}

\author{
Juliana M Argolo ${ }^{1 *}$, Maria de Fatima P de Oliveira ${ }^{2}$, Achilea C Bittencourt ${ }^{3}$, Lourdes Farre ${ }^{1}$ \\ From 15th International Conference on Human Retroviruses: HTLV and Related Viruses \\ Leuven and Gembloux, Belgium. 5-8 June 2011
}

\section{Background}

Infective dermatitis associated with HTLV-1 (IDH) is a recurrent and severe childhood infected form of eczema, that usually begins at 18 months in vertically-infected children. IDH may progress to adult T-cell leukemia/ lymphoma (ATL). Abnormal T cells (ably), including flower cells, were found in the peripheral blood smears of $30 \%$ (9/31) of IDH patients in Bahia, Brazil. Monoclonal integration of provirus assessed by inverted long PCR (ILPCR) was detected in 3 of these patients ( 2 with flower cells and one with ably cells but without flower cells in peripheral blood smear). The aim of this study was to identify the integration sites of the HTLV-1 provirus in host human genome in the IDH patients with monoclonal integration

\section{Materials and methods}

The sequences of the PCR products of these 3 patients obtained by ILPCR were mapped on to the human genome using the Basic Local Alignment Search Tool http://www.ncbi.nih.gov/blast.cgi.

\section{Results}

In the two patients with flower cells, integration sites were detected, respectively, in chromosome 1 (1p34.2) and chromosome 3 (3p11.1). In chromosome 1, the provirus was located within PPM1H gene coding region and in chromosome 3, within alpha satellite DNA sequences. The patient with integration in chromosome 1 also presents HAM/TSP. In the IDH patient without flower cells, integration site was identified at

\footnotetext{
* Correspondence: juargolo@gmail.com

${ }^{11}$ Laboratory of Experimental Pathology, CPQGM, FIOCRUZ, Salvador, Bahia, 40296710, Brazil

Full list of author information is available at the end of the article
}

chromosome 12 (12q14) and was located near the transcriptional start site of GUCA2B gene.

\section{Discussion}

In IDH patients with monoclonal integration, the provirus integration sites can be associated with transcriptionally active regions of the human host genome.

\section{Author details \\ ${ }^{11}$ Laboratory of Experimental Pathology, CPQGM, FIOCRUZ, Salvador, Bahia, 40296710, Brazil. ${ }^{22}$ Department of Internal Medicine, HUPES, Federal University of Bahia, Salvador, Bahia, 40296710, Brazil. ${ }^{33}$ Department of Pathology, HUPES, Federal University of Bahia, Salvador, Bahia, 40296710, Brazil.}

Published: 6 June 2011

doi:10.1186/1742-4690-8-S1-A144

Cite this article as: Argolo et al:: Integration sites of the HTLV-1 provirus in host human genome in the IDH patients with monoclonal integration. Retrovirology 2011 8(Suppl 1):A144.

Submit your next manuscript to BioMed Central and take full advantage of:

- Convenient online submission

- Thorough peer review

- No space constraints or color figure charges

- Immediate publication on acceptance

- Inclusion in PubMed, CAS, Scopus and Google Scholar

- Research which is freely available for redistribution

\section{() Biomed Central}

(c) 2011 Argolo et al; licensee BioMed Central Ltd. This is an open access article distributed under the terms of the Creative Commons Attribution License (http://creativecommons.org/licenses/by/2.0), which permits unrestricted use, distribution, and reproduction in any medium, provided the original work is properly cited. 